\title{
EDWARD AZAR'S PROTRACTED SOCIAL CONFLICT THEORY AND DRIVERS OF SELF-DETERMINATION: THE CASE OF NIGERIA
}

\section{INTRODUCTION}

Since attaining independence on $1^{\text {st }}$ October 1960, de-colonialisation, self-determination, and independence of people under the shackles of foreign rule has been one of the cardinal foreign policy objectives of Nigeria. The state is considered as the giant of Africa, with a currently over 200 million population projected to grow in the coming years (The World Bank, nd). Its population strength and viable military establishment accords the Nigerian army a leadership position in Africa, especially in peacekeeping missions regionally, continentally, and globally. Its multicultural, multi-ethnic, and multi-religious character has proven over the years to be both a blessing and curse, especially with regards to ethno-religious violent conflicts. A country endowed with vast natural resources and green environment, Nigeria has arable and productive land capable of sustaining itself. Nevertheless, the trajectory of agriculture in the country has remained unforthcoming, "production hurdles have significantly stifled the performance of the sector" (FAO, nd). Other than agriculture, "Nigeria is one of the largest and oldest oil producers in Africa. The oil and gas sector is one of the most important sectors in the country's economy, accounting for more than $90 \%$ of the country's exports and $80 \%$ of the Federal Government's revenue" (Nigeria oil \& gas market, nd). With a resilience economy (Okonjo-Iweala, 2009), it currently tops South Africa as the biggest economy in Africa (Naidoo, 2020). Despite its achievements as a nation, building itself as a polity and thereby instituting a national identity has remained progressively slow. The unhealthy colossal political realities in this largest representative of the African continent are often ominous to both immediate and distant neighbours. Since independence, Nigeria has been grappling with ethno-religious politics, which led the country into civil war in 1967. The transition and evolution of the country from three regions to nineteen states and further division into thirty-six states has not dampened the agitation for self-determination - secessionist campaign, be it the Biafra or the Oduduwa and Movement for the Emancipation of the Niger Delta (MEND). Some critics situate these agitations as one of the ugly and curse of colonial bequeathed legacies (Ajaebili, 2015; Akiwowo, 1972; Adetiba, 2013; Badmus, 2009; Olasupo, Oladeji, Ijeoma, 2017; Oyeranmi, 2011). Osinubi and Osinubi (2018), rightly argue that "the colonialist while pretending to carry out a mission of uniting the warring ethnic 
groups, consciously and systematically separated the various Nigerian people thereby creating a suitable atmosphere for conflict." Interestingly, the Nigerian constitution places all ethnic groups on equal footing, but critics of the Nigerian polity argue that ethnic relations is rather characterised by both vertical and horizontal power relations. (Akinwumi, Okpeh, Je'adayibe, 2006: 608; Osinubi, Osinubi, 2018; Saliu, 2005: 9). While the three major tribes (Hausa, Yoruba, and Ibo) are technically on same horizontal plane, other tribes are at the vertical periphery. Protracted ethnic discrimination and political uncertainty in the country has further exacerbated and deepened the clamour for self-determination. The recent social unrest and developments, revolving around herdsmen and farmers across the country, encapsulates the magnitude of ethnic tension. This unrest, though not new, presents dangerous ramifications, for an upcoming general election in 2023. To place the discussion in perspective, existing literature on the subject is reviewed. Thereafter, Edward Azar's protracted social conflict theory is theoretically revisited and probed. Upon laying the theoretical underpinning, the study situates and analyses how economic deprivation, perceived and actual inequality, elite corruption, and foreign interference cross-fertilises, synthesises, and incentivises the spirit of self-determination in Nigeria. Lastly, the study argues that instead of seeking self-determination or territorial disintegration, the polity of Nigeria should historically revert to the practice of regionalism.

\section{REVIEW OF LITERATURE}

In post-colonial Africa, the politics of ethno-nationalism have largely dominated the political landscape, with attendant divisive, brutish (as in the case of Rwanda and other violent civil wars,) and retrogressive impacts vis-à-vis development. The rarity of ethnic cooperation predicated on mutual distrust and lack of enthusiasm for a common purpose, has given way to ethno- and sub-nationalism and a subsequent weakening of institutions and perception of ethnic inequality (Fenske, Zurimendi, 2017; Vickers, 2001). Mwakikagile (2001) like many others, contends that the policies of the Mega States - Big Powers and Mega Corporations in Africa have added to the ethnic tensions on the continent. The selfish interest of the former either alienate the locals or becomes the reason why governments in countries like Nigeria are considered as puppets by the disenfranchised locals.

Since independence, politics and governance in Nigeria have generally been driven and punctuated by ethno- and sub-nationalism, which in turn escalates into the incessant ethnic related crises (Achimugu, Ata-Agboni, Aliyu, 2013). The protraction of religio-ethnic conflicts, and the failure to have a true national identity, situates Nigeria amongst the nations plagued by the problem of nation building. Agbiboa (2013) argues that political mobilisation along politicised ethno-religious lines and the weight of inherited colonial policies has a significant ramification on Nigeria's national unity. Driving the case further, Madueke (2019) suggests that "colonial antecedents contributed to setting in motion rivalries that have remained salient in present day politics of identity and contestations," while Osinubi and Osinubi (2018) implicate colonial project of transforming ethnic heterogeneity into homogenous "mission of uniting the warring ethnic groups, 
consciously and systematically separated the various Nigerian people thereby creating a suitable atmosphere for conflict" - the fallout of these incessant conflicts and the mounting sense of discrimination further explains the clamour for self-determination.

In Nigeria, the lack of true federalism engenders the agitation for self-determination, as ethnic tensions get animated on perceived discrimination, unfair representation and treatment with particular reference to the distribution of national wealth (Suberu, 2001). The fragility of the Nigerian federalism does not simply undermine and fracture the building blocks of ethnic accommodation, it becomes the source of acrimonious ethnic relations, sparking (Adele, 2002: 33) political yearning that seeks an alternative to an unforthcoming federalism. For Nigeria to join the league of prosperous nations, Wani and Suwirta (2013) argue for the accommodation of ethnic heterogeneity, favourable decentralisation of power and true socio-political restructuring geared at maintaining social justice for all without any discrimination.

The Second World War marked the end of European colonialism and the revival of the principle of self-determination globally (Whelan, 1992). As a mark of disgruntlement against colonial rule, the slogan of decolonisation was punctuated by self-determination and political independence. This slogan transformed into the cornerstone of foreign policy of many African states and one of the cardinal reasons for the creation of the Organisation of African Unity (OAU) - now African Union (AU) (Addo, 1988: 183-184; Kamanu, 1974). Several years later, a second wave and demand for self-determination remerged, but unlike the previous, it was directed at local African authorities, leading to internal strife - nation against nation and civil wars. In the case of Nigeria, the vast number of literature produced on the second wave of self-determination is mostly centred on the Igbo people, the third major ethnic group in the country (Islam, 1985; Kamanu, 1974: 361; Nixon, 1972; Onuoha, 2013; Panter-Brick, 1968; Whelan, 1992: 40). The trajectory of the literature changed and an additional value was added when the Ijaw ethnic group (of the Niger Delta) seeded and demonstrated militarily their yearning for self-determination (Osaghae, 1999: 90; Welch, 1995). In recent times, the scope of self-determination and secessionism has grown and matured to include a segment of the Yoruba - the second major ethnic group, demanding for Oduduwa republic (Johnson, 2017: 96). Although Ibrahim (1999: 14) posits that the idea of Oduduwa republic stretches back to the 1980s. It stemmed from the frustration following Obafemi Awolowo's defeat during the 1983 election and that frustration remerged on the annulment of the 1993 elections, which was generally believed to have been won by Moshood Abiola (a Yoruba). Ibrahim's argument is augmented by Osaghae (1999: 90) who claimed that "on account of Northern domination" the idea of Oduduwa Republic remains alive.

\section{THEORETICAL CONSIDERATION: EDWARD AZAR'S PROTRACTED SOCIAL CONFLICT THEORY}

Edward Azar's work remains one of the best approaches that changed the way conflict is understood and analysed. His ability to diagnose conflict as a phenomenon outside and beyond the conventional interstate wars further illuminates our understanding of 'deep-rooted conflicts' (Burton, 1987), 'intractable conflicts' (Kriesberg, 
Northrup, Thorson, 1989) and protracted social conflict. Azar's conceptual exposition radically generates a powerful intellectual discourse that calls for the revision of prevailing Clausewitzean idea of war (Ramsbotham, 2005: 111), which situates war as an extension and attendant exhaustion of diplomacy amongst states. Though Azar challenged the overemphasis of interstate war and the proclivity to ignore "covert, latent or non-violent conflict', nevertheless, his argument does not preclude the role of the state, either to 'satisfy or frustrate basic communal needs, thus preventing or promoting conflict (Azar, 1990: 10-12). Azar's contribution to the dynamics of violent conflict exposes the conceptual lacunae, in which the "termination of violent acts is often equated with the state of peace" (Miall, Ramsbotham, Woodhouse, 2000: 94-95). Contextually, 'protracted social conflict' (PSC) is different in nature and scope, because it is within rather than between states. Theoretically, it is centred on four clusters of variables which are the preconditions not just for their intractability and protraction, but also their transformation to high level of intensity.

Firstly, the first unit of analysis of PSC is its " "communal content' characterised by identity group - racial, religious, ethnic, cultural, and others" (Azar, 1986: 62). The core problem of most conflicts in post-colonial societies is explicable in many ways, but Azar believes they all hinge on the "disarticulation between the state and society as a whole" (Azar, 1990: 7), an imbalance relationship characterised by incompatibility of goals (Galtung, 2009) not just amongst group with dissimilar identities, but also between state and society. According to Azar, the 'disarticulation' owe much to the bequeathed colonial legacy that enables discrimination, wherein state machinery is "dominated by a single communal group or a coalition of a few communal groups that are unresponsive to the needs of other groups in the society' which 'strains the social fabric and eventually breeds fragmentation and protracted social conflict" (Miall, Ramsbotham, Woodhouse, 2000: 95).

Secondly, relative deprivation is one of the derivatives of sociological concepts (Gurney, Tierney, 1982), which suggest the "feeling of being disadvantaged" or "perceived discrepancy between personal status and the status of some relevant other(s)" (Schulze, Krätschmer-Hahn, 2014), or "the judgment that one is worse off compared to some standard accompanied by feelings of anger and resentment" (Smith, Pettigrew, Pippin, Bialosiewicz, 2012). Following the sociological intellectual tradition, Azar argues that the failure to address both 'perceived and actual' deprivation generates both conflict habit and behaviour - "Grievances resulting from need deprivation are usually expressed collectively. Failure to redress these grievances by the authority cultivates a niche for a protracted social conflict" (Azar, 1990: 9). Azar associates these grievances to the deprivation of immutable rights and needs (security needs, development needs, political access needs, and identity needs) which are ontological and non-negotiable. For Azar, an individual or group sensitivity towards these needs means secured development, and therefore "protracted conflict leads one to conclude that peace is development in the broadest sense of the term" (Azar, 1986: 69).

Thirdly, governance quality is the next unit of analysis in Azar estimation. For $\mathrm{him}$, it is critical in the satisfaction or frustration of individual and identity group. The dearth of quality governance portends PSC, as "Most states which experience protracted social conflict tend to be characterised by incompetent, parochial, fragile, and 
authoritarian governments that fail to satisfy basic human needs" (Azar, 1990: 10-11). Interestingly, Azar further argues that in societies grappling with good governance, rapid population, and restricted 'political authority' - 'authority 'tends to be monopolized by the dominant identity group or a coalition of hegemonic groups' who see other member of the society as unequal. This disparate treatment does not merely translate into exclusion, it also becomes the limiting of access (to opportunities) of the 'other' or 'group', which eventually precipitates the 'crisis of legitimacy', an important variable (recipe) for protracted social conflict.

Fourthly, in Azar's estimation, 'international linkage' is an important variable which factors political-economic relations and underscores structural dependency within the international economic system. Like many other analysts of world system and postcolonial structures and institutions, Azar also avows that the "formation of domestic social and political institutions and their impact on the role of the state are greatly influenced by the patterns of linkage within the international system" (Azar, 1990: 11).

\section{An evaluation of Agitation for Self-Determination in the light of PSC}

Since independence, the agitations for self-determination and the associated political unrest have been central to the resilience of the Nigerian polity. As the most populous African nation, Nigeria has been struggling to resolve the question of communal identity and keep together its multitude of communal group. The forceful marriage of the multiple identities by and for colonial expediency remains one of the post-colonial dilemmas for this oil rich state. While successive discussion offers a critical evaluation of recent self-determination agitation in Nigeria in the light of Azar's analysis of protracted social conflict, scholars have made scholarly venture to use same theoretical lens in dissecting the Nigeria's Niger-Delta Protracted Conflict (Adeosun, 2020) and how same theory best explains the ongoing social conflicts in Nigeria (Sango, 2009).

\section{Communal Content}

Other than its sociological and historical root, the construct of an identity makes way for cognitive positioning and an affiliation to a particular group, a niche in the larger social and political environment. Azar argues that a defining element of 'new form' of conflicts, outside the realm of traditional - interstate wars, is the communal content. While the latter is characterised by self-conceited image, pride, and prestige of a country within the comity of nations, and the fight over geographical spaces, the new form of conflicts and the consequent implications hinge on primordial forces and sentiments. In new form of conflicts, group identity - racial, religious, ethnic, cultural, and others, are particularly instructive and instrumental. Additionally, the identity factor becomes more imminent amidst a "disarticulation between the state and society as a whole" (Azar, 1990: 7). Similar to the traditional conflict, where states are perpetually struggling to maximise power and attain respect, it is equally true in the new form of conflict, as self-respect of ethnic group and the protection of communal identity are 
the unassailable priority. In today's Nigeria, ethno-nationalism is increasingly overriding supra-nationalism, due to host of reasons (Badmus, 2009; Gilbert, 2013; Olasupo, Oladeji, Ijeoma, 2017; Uduma, 2013). The identity crisis explicates the first experience of Nigerian civil war in 1967. Most recently, the increasing breakdown of law and order and the controversial herdsmen saga, has become a major internal security concern in Nigeria (Ajala, 2020; Olaniyan, Yahaya, 2016). The absence of a concerted and pragmatic response by the federal government to address the issue (Ujumadu, Agbo, 2021), particularly as it involves cattle rearers, who are ethnically Fulani, sends an unresponsive signal and engenders a swift conclusion of state partiality and insensitivity towards the affected victims in the Southwest of the country (Ajadi, 2021; BBC, 2021; Oyeleke, 2021). The herdsmen crisis has renewed the call for self-determination (Amaize, Ahon, Olayemi, 2020; Olumide, 2020; Ujumadu, Agbo, 2021) amongst those who clamour for legitimate self-defense and protection of their communal ethos through an autonomous status. The herdsmen crisis underpins Azar's argument that in post-colonial multi-communal societies, the states do not only act unresponsive to the pressing needs of the people, but it is equally "dominated by a single communal group or a coalition of a few communal groups that are unresponsive to the needs of other groups in the society which strains the social fabric and eventually breeds fragmentation and protracted social conflict" (Miall, Ramsbotham, Woodhouse, 2000: 95). There is no paucity of literature on the intersection of colonialism and ethnic conflict in post-colonial societies like Nigeria. Amongst other reasons, ethnic conflict has been largely associated with the unholy colonial wedlock, which clubbed multiple identities as one. Critics of this political union consider it as a major source of animosity and acrimonious relations amongst ethnic groups (Adetiba, 2013; Badmus, 2009; Blanton, Mason, Athow, 2001; Oyeranmi, 2011; Osinubi, Osinubi, 2018). Therefore the state of affairs in most African societies and particularly in Nigeria typifies colonial legacy and the unfinished controversial business of north and south amalgamation.

\section{Deprivation of communal needs}

In a country where regions (collection of states) are potential food baskets and endowed with resources worthy of being autonomous, the issue of basic deprivation should not be a subject for debate. Buttressing Maslow's hierarchy of needs - physiological, safety-security, belongingness, esteem, and self-actualization (Taormina, Gao, 2013), Azar argues that when deprivation of human needs, i.e. security needs, development needs, political access needs and identity needs (cultural and religious expression) becomes too imminent and beyond the threshold of endurance, perseverance, and forbearance, it resultantly provokes grievances which is an underlying source of PSC (Miall, Ramsbotham, Woodhouse, 2000: 96). In his own words, "Grievances resulting from need deprivation are usually expressed collectively. Failure to redress these grievances by the authority cultivates a niche for a protracted social conflict" (Azar, 1990: 9). In the case of Nigeria, the deprivation of above described needs can be dissected on two fronts.

One, it is one of the major driving reasons for self-determination, inspired by the feeling of ethnic subjugation and marginalisation (Achimugu, Ata-Agboni, Aliyu, 
2013: 55; Orji, 2001; Osaghae, 1996). One common narrative in Nigeria is that, at the expense of other ethnic groups, a particular ethnic group rules and dominates, while others are underrepresented at the national front, in terms of sharing and allocation of power and national resources (Anugwom, 2000; Mustapha, 2005: 10). This narrative and perception has proven disruptive for a healthy and smooth drive towards democracy, where every constituent part of the polity is treated equitably just. Even when successive governments tend to be represented as composition of all 'ethnicities' still the state institutions are considered the tools of exploitation in the hand of the north (frustrating basic communal needs), sowing the seeds of conflict, and furnishing a cogent reason for self-determination.

Two, deprivation of communal needs can be provocative and offensive to cultural sensibility, particularly when the sense of ethnic superiority is socially constructed and rooted in history and cultural heritage. The indelible history of Nigeria underlines the volatility of such deprivation, especially when shrouded in cultural and religious expressions. Additionally, these needs are ontological and non-negotiable so that, if conflict comes, it is likely to be intense, vicious, and irrational as demonstrated by the civil war in 1967 and other ethnic disturbances that have rampaged the country over the course of its existence. Badmus (2009) rightly posits "conflict are function of social frustration of the disadvantaged ethnic groups arising from failed expectations of government to deliver their basic socio-economic needs." In today's Nigeria, self-determination is discussed as an antidote to remedy the deprivation of communal needs and a prudent approach towards granting political autonomy to ethnic minorities or any aggrieved group and most importantly, a safe passage that could shield the country from the verge of another unwarranted civil war, with regional and global implications. It is also considered as an instrument of righting the wrong of the past and as a political structure, "which allows each ethnic-nationality some latitude of selfrule/governance" (Olasupo, Oladeji, Ijeoma, 2017: 261).

\section{Governance Quality and State}

For some Nigerians, the commonwealth of Nigeria is a failure, not as a failed state, but because the state is lax in its responsibility to safeguard the social contract between the individual and the society, between the society and the state, and between the constituent states and the central government. Individual and group's expectations from the state is increasingly dwindling, a growing fracture of state - people social contract (Folarin, 2020; Guardian, 2020). Critics of the country argue that the country is experiencing freewheel trajectory course, most especially amidst the mounting law and order dislocation and the attendant developmental deficit (Aljazeera, 2020; Campbell, 2020; Hendrix, 2016; Husted, Blanchard, 2020; Lawan 2011). Under the Nigerian constitution, the state is entrusted with the immutable responsibility to create and facilitate an enabling tranquil climate for socio-economic development and enhancement of the citizens. When such constitutional responsibility ceases to be a manifest reality, it precipitates the crisis of legitimacy (Azar, 1990) and stimulates frustration and disgruntlement. The dearth of good governance (sense of responsibility, account- 
ability and transparent) is staggering and increasingly drawing the country to the tipping point of disintegration, as elucidated by the loud drum of self-determination and regional autonomy by the aggrieved ethnic group (Aro, Ani, 2017; Ayoade, 2018; Human Rights Watch, 2003; Onuoha, 2013; Welch, 1995). Since the return of democracy on 29 May, 1999, the country has been working to sustain its democratic dispensation. In the background of its democratic climate, it is hard to label Nigeria as an authoritarian state, yet the character of successive governments underscores Azar's estimation of "authoritarian governments that fail to satisfy basic human need" (Azar, 1990: 10-11). By Azar's estimation, good governance requires the dispensation of equitable justice and the treatment of all members of the political community as legally equal. Conversely, the unfolding reality in Nigeria drives the spirit of self-determination, premised on the argument that they have long been deprived of legal equality and benefit. According to Azar, the monopoly of the dominant identity group or a coalition of 'hegemonic groups' often exacerbate the precarious situation. In the case of Nigeria, the Hausa-Fulani (northern elites) is mostly singled out as the 'dominant or hegemonic group identity', which use the state to maximize their interests at the expense of others. It is however imperative to say that the symbol of oppression and domination transcends this group. The oppression and corruption of the ruling elites - an amalgam of varied identities, who are the true dominant group has contributed largely to the sense of exclusion nurtured by the generality of Nigerians. Although Azar focused on the developing nations, particularly those characterised by 'rapid population growth and limited resource base', in the case of Nigeria, the former is true, but the latter is rather resource curse. Nigeria is one of the most naturally endowed countries in terms of natural resources, an oil rich nation, where poverty is sadly the reflection and dividends of its oil economy.

Governance in larger context involves the responsiveness of the rulers towards the plight of the citizens. In Nigeria, the degree of inequality and the attendant poverty, drives the conclusion that the ruling elites are merely undisturbed by people's lot and are rather satiated in the 'the misuse of public power for private gain' - corruption. Analysing the root of elite corruption in Nigeria, Osoba (1996: 371) argues that it has always been the "principal means of private accumulation during the decolonisation period" and became endemic in post-independence Nigeria (Ojukwu, Shopeju, 2010). While there is an international narrative on Nigeria's overt corruption, Mustapha (2010) conceptually explores the 'unofficial corruption of the state' - a way of life which successive 'governments neither wish to, nor can, control' (Osoba 1996: 371; ), as there is a 'combination of intra-elite rancour and political intrigue' which poses gravest threats to anti-corruption campaigns (Adebanwi, Obadare, 2011). Buttressing the latter, Abu and Staniewski (2019) opine "corruption and its determinants (economic development, political rights, military expenditure, rents, civil liberties and openness) have a long-run relationship." Invariably, corruption as an endemic disorder in the Nigerian system explains the awful yet perpetual assessments of the country by international NGO (Campbell, 2020). Concomitantly, corruption has played significant role in the increasing gulf of inequality and the uneven distribution of national wealth, which further underscores bad governance. All of these anomalies cross-fertilise, synthesise, and incentivise the spirit of self-determination, particularly amongst 
those who believe they can better govern themselves and optimally use their natural resources without the dictate and dominance of the central government, purportedly under the control of the Hausa-Fulani.

Hence, the laxity in governance is not simply a recipe for PSCs, but a catalyst for self-determination. Whereas the future of Nigeria fundamentally rests on communal responsibility of the constituent parts, access to and satisfaction of basic human needs, on the contrary, the ground realities speak loudly different. To safe the country from disintegration, the dominant elite and group has never ceased to downplay the potential success of self-determination. Amidst a growing mistrust and wariness of Nigeria's federalism, the federal character and constitution is often employed to undermine the agitation of self - determination. In certain estimation, the Nigerian federalism is an overdue relic of independence, requiring both honest and conscious political reengineering. The laxity of federalism lends support to the argument that federalism undermines and impairs the growth of states - similar to the laudable achievements of the regions before independence. To this end, certain section of the country that is frustrated and disdainful of the system, vehemently see restructuring - i.e., self-determination, along ethnic and regional line as the most plausible way to anchor the country further. A long reminiscence of the 1950s generates the debate that being separated regionwise, will improve good governance, accord regional governments ability to serve their kinsmen closely, address 'individual and identity group needs' much better than a federal government.

\section{CONCLUSION}

Over the course of many years, Nigerians have endured economic deprivation, inequality, stagnant development, elite corruption, and perceived ethnic discrimination and marginalisation of varying degree. These anomalies are not just preconditions and incentives for protracted social conflict as asserted by Azar, they are also the underlying reasons for self-determination agitation. Despite the protraction and cross-fertilisation of these socio-political and economic challenges; the resultant selfdetermination cannot be broadly interlocked with structural, institutional, and vertical inequality, it is rather horizontal (Archibong, 2018; Jayaraj, 2006; Ukiwo, 2008). From a group-level analysis, inequality has become endemic to the Nigerian polity, all due to the monopoly, exploitation of state's institutions and resources by few elites, operating like political mafias and running state towards an end of cronyism. The outcome is corruption and cronyism implicate the elites, whose self-centred way of live endangers the masses. Corruption and inequality are directly proportional in Nigeria. More often than not, the case of inequality and marginalisation, and the resultant self-determination is erroneous placed on the Hausa-Fulani ethnic group. Such accusation is an overblown faulty assertion. Even when few Hausa-Fulani enjoys maximum power and access to resources, the generality of same tribe are mostly the deprived, struggling with poverty.

Meanwhile, it is seemingly hard to convince most Nigerians that the country is on the right political and economic trajectory. The level of human capital flight, espe- 
cially of the youth, the search for greener pasture in Europe and the troubling death count on the Mediterranean Sea, the mounting socio-economic deprivation, perceived structural inequality, elite corruption, ethno-religious conflicts and the larger internal and external insecurity are probably factors upon which some might be pressed to dub Nigeria as a failed state. Since 1967 when the country experienced a civil war, it has survived and demonstrated resilience in the face of countless socio-political and economic trials. The recent herdsmen saga and proliferation of insecurity has played significant role is galvanising the demand for self-determination and territorial disintegration. However, the cost of disintegration will transcend the boundaries and capacity of Nigeria, there is no doubt of the regional and international ramifications.

Firstly, being the most populous country in West Africa and the entire continent of Africa, the entire continent, even countries across the Atlantic will be affected by the slightest volatile political unrest in Nigeria, most especially if it becomes protracted. In addition to the enduring internal displacement which an eventual disintegration will cause, its huge population will constitute a colossal nuisance along regional, continental, and international borders.

Secondly, being a major oil exporter (and importer) the disruption of the oil supply in Nigeria will certainly be impactful on global oil price, the same manner Ivory Coast electoral turmoil hiked the prices of cocoa globally (Hawkes, 2010). The event of a civil unrest - war geared at multiple self-determinations could turn a relatively peaceful Nigeria into yet another troubled spot. Because of its ethnic complexity and religio-political sentimentality, disintegration of Nigeria will unquestionably be costly. Besides exacerbating the already insecurity in the country, it will compound the menace of Boko Haram and jeopardise whatever accomplishment is made by the regional military coalition against the extremist group.

Thirdly, to stabilise and normalise the 'new created regions' will engulf serious political capital and acumen. It might take ten of years, if not more to achieve, therefore the regions could be vulnerable to political turmoil, uncertainty, and protracted economic challenges. This will be more challenging when the same crop of elites rule over the 'new created regions'.

Fourthly, even as the tidal wave of self-determination gathers momentum, Nigeria as it is, remains an interconnected polity. People to people contact, interethnic relations, and interstate socio-economic intercourse have long been a tradition. The idea of a separation will merely destroy the long laboured interethnic rapport and whatever can be considered as the sense of being a Nigerian.

Fifthly, without a congenial, connected, and progressive regionalism, the separate regions will suffer for smooth connectivity. For instance, complication in cross-regional border management and mobility. This will further complicate food shortage and interregional mobility.

Sixthly, rather than chanting the slogan of self-determination, the Nigerian polity should revert to the practice of congenial, connected, and progressive regionalism, a genuine federalism that characterised the very foundation of Nigeria - years before and after independence. Nigeria as a country needs a political reawakening geared at reproducing the semblance and ingenuity of Sir Ahmadu Ibrahim Bello, Sardauna of Sokoto, Chief Obafemi Awolowo and Nnamdi Azikiwe. The creativity of these politi- 
cal geniuses produced indelible landmarks that even present and future Nigeria may not surpass, but at the least be consolidated. A genuine federalism must be progressive and must ensure true autonomy to the constituent parts. The reality of a progressive, self-developing, and self-governed regions in present Nigeria will be subject to constitutional amendment and political restructuring. The new constitution must not only embrace the compelling realities of present Nigeria, it must strike a genuine balance between federalism and confederation. Foreign policy, defense, monetary policy, and a single market currency (the likes of the Eurozone) would be decided, managed and subject to collective decision making processes. Internal revenue and management of the regions must be the sole responsibility of regional administration. The difference between the proposed and current arrangement is that, there will be no reliance on the central government and the latter will ceased to control the resources of the regions.

\section{REFERENCE}

Abu N., Staniewski W. M. (2019), Determinants of corruption in Nigeria: evidence from various estimation techniques, "Economic Research-Ekonomska Istraživanja," Vol. 32, No. 1.

Achimugu H., Ata-Agboni U. J., Aliyu A. (2013), Ethnicity, Ethnic Crisis, and Good governance in Nigeria: Implications for Sustainable National Development, "Public Policy and Administration Research", Vol. 2, No. 12.

Addo M. (1988), Political Self Determination within the Context of the African Charter on Human and Peoples'Rights, "Journal of African Law", 32, Vol. 2.

Adebanwi W., Obadare E. (2011), When corruption fights back: democracy and elite interest in Nigeria's anti-corruption war, "The Journal of Modern African Studies", Vol. 49, No. 2.

Adele J. L. (2002), Ethnic conflict and federalism in Nigeria, "ZEF Discussion Papers on Development Policy", No. 49, University of Bonn, Center for Development Research (ZEF), Bonn.

Adeosun A. B. (2020), The Nigeria's Niger-Delta Protracted Conflict: How Relevant is Azar's Protracted Social Conflict Theory to the Analysis of the Conflict?, "Diverse Journal of Multidisciplinary Research", Vol. 2, Issue 3.

Adetiba C. T. (2013), Ethnic Conflict in Nigeria: A Challenge to Inclusive Social and Political Development, Doctor of Philosophy Dissertation. University of Fort Hare, South Africa.

Agbiboa D. (2013), Ethno-religious Conflicts and the Elusive Quest for National Identity in Nigeria, "Journal of Black Studies", Vol. 44, No. 1.

Ajadi A. Scapegoating the Fulani Dehumanises Us All, "Premium Times", https://www.premiumtimesng.com/ opinion/443878-scapegoating-the-fulani-dehumanises-us-all-by-adewale-ajadi.html (19.02. 2021).

Ajaebili C. (2015), A Century after Amalgamation: Reflections on History and Nation Building in Nigeria, 1914-2014, "Journal of the Historical Society of Nigeria", Vol. 24.

Ajala O. (2020), New drivers of conflict in Nigeria: an analysis of the clashes between farmers and pastoralists, "Third World Quarterly", Vol. 41, No. 12.

Akinwumi O., Okpeh O. O., Je'adayibe G. D. (2006), Inter-group Relations in Nigeria during the 19th and 20th Centuries, Aboki Publishers, Makurdi.

Akiwowo A. (1972), Tribalism and Nation-Building in Nigeria, "Il Politico", Vol. 37, No. 1.

Amaize E., Ahon F., Olayemi P., Vanguard, https://www.vanguardngr.com/2020/05/herdsmen-bandits-attacks-well-take-our-destiny-in-our-hands-delta-govt/ (27.05.2020). 
Anugwom E. E. (2000), Ethnic Conflict and Democracy in Nigeria: The Marginalisation Question, "Journal of Social Development in Africa", Vol. 15, No. 1.

Archibong B. (2018), Historical origins of persistent inequality in Nigeria inequality in Nigeria, “Oxford Development Studies", Vol. 46, No. 3.

Aro G., Ani K. (2017), A Historical Review of Igbo Nationalism in the Nigerian Political Space, "Journal of African Union Studies", Vol. 6, No. 2/3, DOI: 10.2307/26886164.

Ayoade S. (2018), Self-Governing Protectorate-Panacea to Yoruba Self Determination? A forensic Assessment of the Feasibility, Pros and Cons, "Peer Research Journal of Forensics \& General Sciences", Vol. 2, No. 4, ID.000143.

Azar E. (1985), Protracted International Conflicts: Ten Propositions, "International Interactions", Vol. 12, No. 1.

Azar E. (1990), The Management of Protracted Social Conflict: Theory and Cases, Elgar, Aldershot-Dartmouth.

Badmus I. (2009), Under Reconstruction: Ethnicity, Ethnic Nationalism, and the Future of the Nigerian State, "Verfassung Und Recht in Übersee/Law and Politics in Africa, Asia and Latin America", Vol. 42, No. 2.

Blanton R., Mason T., Athow B. (2001), Colonial Style and Post-Colonial Ethnic Conflict in Africa, "Journal of Peace Research", Vol. 38, No. 4.

Burton J. (1987), Resolving Deep-Rooted Conflict: A Handbook, University Press of America, Lanham, MD.

Campbell J. (2020), Perceptions of Corruption in Nigeria Remain High, According to NGO, "Council on Foreign Relations", https://www.cfr.org/blog/perceptions-corruption-nigeriaremain-high-according-ngo.

Campbell J., The Prospect of Local Policing Amid Security Breakdown in Nigeria, "Council on Foreign Relations", https://www.cfr.org/blog/prospect-local-policing-amid-security-breakdown-nigeria (14.07.2020).

Duruji M. M. (2008), The Changing Context of Ethno-Nationalism in Nigeria, "UNILAG Journal of Politics", Vol. 4.

FAO (nd), Nigeria at a glance, http://www.fao.org/nigeria/fao-in-nigeria/nigeria-at-a-glance/en/.

Fenske J., Zurimendi I. (2017), Oil and Ethnic Inequality in Nigeria, "Journal of Economic Growth", Vol. 22.

Folarin S., Nigeria is still struggling at 60. But hope is still alive, "The Conversation", https://theconversation.com/nigeria-is-still-struggling-at-60-but-hope-is-still-alive-146943 (02.10.2020).

Galtung J. (2009), Theories of Conflict: Definitions, Dimension, Negations, Formation, Transcend University Press, Oslo.

Gilbert L. D. (2013), Revisiting Ethno-Nationalism in the Niger Delta of Nigeria: An Interrogation of its Achievements and Prospects, "International Affairs and Global Strategy", Vol. 16.

Hawkes A., Cocoa prices rise after Ivory Coast election turmoil, "The Guardian”, https://www.theguardian.com/world/2010/dec/22/cocoa-prices-rise-ivory-coast (22.12.2010).

Hendrix S. (2016), Combating Terrorism and Violent Extremism in Nigeria: Defining a New Approach to Winning Modern Jihadist Conflict, "The International Lawyer", Vol. 49, No. 3, DOI: $10.2307 / 26415586$.

Hugh M., Ramsbotham O., Woodhouse T. (2000), Contemporary Conflict Resolution: The prevention, management and transformation of deadly conflicts, Polity Press, Cambridge.

Human Rights Watch (2003), From Self-Determination Group to Vigilantism, https://www.hrw.org/ reports/2003/nigeria0203/nigeriaopc0203-02.htm. 
Husted F. T., Blanchard P. L. (2020), Nigeria: Current Issues and U.S. Policy, "Congressional Research Service", https://fas.org/sgp/crs/row/RL33964.pdf.

Ibrahim J. (1999), Political Transition, Ethnoregionalism, and the "Power Shift" Debate in Nigeria, "Issue: A Journal of Opinion", Vol. 27, No. 1.

Islam M. (1985), Secessionist Self-Determination: Some Lessons from Katanga, Biafra and Bangladesh, "Journal of Peace Research", Vol. 22, No. 3.

Jayaraj D., Subramanian S. (2006), Horizontal and Vertical Inequality: Some Interconnections and Indicators, "Social Indicators Research", Vol. 75, No. 1.

Joan N. G., Tierney K. (1982), Relative Deprivation and Social Movements: A Critical Look at Twenty Years of Theory and Research, "The Sociological Quarterly", Vol. 23, No. 1.

Johnson I. (2017), The Church and Politics in the Niger Delta, "Journal of the Historical Society of Nigeria", Vol. 26.

Kamanu O. (1974), Secession and the Right of Self-Determination: An O.A.U. Dilemma, "The Journal of Modern African Studies", Vol. 12, No. 3.

Kriesberg L., Northrup T., Thorson S. (eds.) (1989), Intractable Conflicts and Their Transformation, Syracuse University Press, Syracuse, NY.

Lawan M. (2011), Law and Development in Nigeria: A Need for Activism, "Journal of African Law", Vol. 55, No. 1.

Madueke K. L. (2019), The Emergence and Development of Ethnic Strongholds and Frontiers of Collective Violence in Jos, Nigeria, "African Studies Review", Vol. 62, No. 4.

Mustapha A. R. (2005), Ethnic Structure, Inequality and Governance of the Public Sector in Nigeria, “CRISE” Working Paper No. 18, https://assets.publishing.service.gov.uk/ media/57a08c97ed915d3cfd0014aa/wp18.pdf.

Mustapha M. (2010), Corruption in Nigeria: conceptual \& empirical notes, "Information, Society and Justice", Vol. 3, No. 2.

Mwakikagile G. (2001), Ethnic Politics in Kenya and Nigeria, Nova Science Publishers, Huntington, N.Y.

Naidoo P., Nigeria Tops South Africa as the Continent's Biggest Economy, "Bloomberg", https://www. bloomberg.com/news/articles/2020-03-03/nigeria-now-tops-south-africa-as-the-continent-sbiggest-economy (03.03.2020).

Nigeria oil \& gas market - growth, trends, covid-19 impact, and forecasts (2021-2026), "Mordor Intelligence", https://www.mordorintelligence.com/industry-reports/nigeria-oil-and-gasmarket.

Nigeria: Army to enforce 'law and order' as protests escalate, "Aljazeera", https://www.aljazeera. com/news/2020/10/15/why-do-women-in-italy-find-their-name-on-grave (15.10.2020).

Nixon C. (1972), Self-Determination: The Nigeria/Biafra Case, "World Politics", Vol. 24, No. 4, DOI: $10.2307 / 2010453$.

Ojukwu C., Shopeju J. O. (2010), Elite corruption and the culture of primitive accumulation in 21st century Nigeria, "International Journal of Peace and Development Studies", Vol. 1, No. 2.

Okonjo-Iweala N. (2009), Africa's Growth and Resilience in a Volatile World, "Journal of International Affairs", Vol. 62, No. 2.

Olaniyan A., Yahaya A. (2016), Cows, Bandits, and Violent Conflicts: Understanding Cattle Rustling in Northern Nigeria, “Africa Spectrum”, Vol. 51, No. 3.

Olasupo O., Oladeji I. O., Ijeoma E. O. C. (2017), Nationalism and Nationalist Agitation in Africa: the Nigerian Trajectory, "The Review of Black Political Economy", Vol. 44, https://doi. org/10.1007/s12114-017-9257-x. 
Olumide S., Rumblings of discontent and demand for Oodua republic, "The Guardian", https://guardian.ng/politics/rumblings-of-discontent-and-demand-for-oodua-republic/ (20.09.2020).

Onuoha G. (2013), Cultural interfaces of self-determination and the rise of the neo-Biafran movement in Nigeria, "Review of African Political Economy", Vol. 40, No. 137.

Orji I. E. (2001), Issues on Ethnicity and Governance in Nigeria: A Universal Human Rights Perspective, "Fordham International Law Journal", Vol. 25, No. 2.

Osaghae E. (1996), Human Rights and Ethnic Conflict Management: The Case of Nigeria, "Journal of Peace Research", Vol. 33, No. 2.

Osaghae E. (1999), Exiting From the State in Nigeria, "African Journal of Political Science/Revue Africaine De Science Politique", Vol. 4, No. 1.

Osinubi T. S., Osinubi S. O. (2018), Ethnic Conflicts in Contemporary Africa: The Nigerian Experience, "Journal of Social Sciences", Vol. 12, No. 2.

Osoba S. (1996), Corruption in Nigeria: Historical Perspectives, "Review of African Political Economy", Vol. 69.

Oyeleke S., Herdsmen: Some persons, groups desperate to incite ethnic violence DSS, "Punch", https://punchng.com/herdsmen-some-persons-groups-desperate-to-incite-ethnic-violencedss/ (03.02.2021).

Oyeranmi S. (2011), The Colonial Background to the Problem of Ethnicity in Nigeria: 1914-1960, "Journal of History and Diplomatic Studies", Vol. 8.

Panter-Brick S. (1968), The Right to Self-Determination: Its Application to Nigeria, "International Affairs", Vol. 44, No. 2, DOI: 10.2307/2613122.

Ramsbotham O. (2005), The Analysis of Protracted Social Conflict: A Tribute to Edward Azar, "Review of International Studies", Vol. 3, No. 1.

Saliu A. H. (2005), Nigeria under Democratic Rule, 1999-2003, Vol. 2, University Press PLC, Ibadan.

Sango T. J. (2009), Managing protracted social conflict in Nigeria: The role and relevance of traditional institutions of governance, in: The 3rd Annual International Conference of Nigerian Students (ICONS) 2009, 4th-5th April 2009, Hull University, Hull.

Schulze M., Krätschmer-Hahn R. (2014), Relative Deprivation Theory, in: Encyclopedia of Quality of Life and Well-Being Research, (ed.) A. C. Michalos, Springer, Dordrecht, https://doi. org/10.1007/978-94-007-0753-5_2457.

Smith J. H., Pettigrew F. T., Pippin M. G., Bialosiewicz S. (2012), Relative Deprivation: A Theoretical and Meta-Analytic Review, "Personality and Social Psychology Review", Vol. 16, No. 3 .

Suberu T. R. (2001), Federalism and Ethnic Conflict in Nigeria, United States Institute for Peace, Washington, D.C.

Sunday Igboho: 'Put law to ban north to south cattle grazing', Kano governor Abdullahi Ganduje tell Nigeria goment, "BBC", https://www.bbc.com/pidgin/tori-55879866 (31.01.2021).

Taormina R., Gao J. (2013), Maslow and the Motivation Hierarchy: Measuring Satisfaction of the Needs, "The American Journal of Psychology”, Vol. 126, No. 2, DOI: 10.5406/amerjpsyc.126.2.0155.

The World Bank, Population, total - Nigeria, https://data.worldbank.org/indicator/SP.POP. TOTL?locations $=\mathrm{NG}$.

Uduma O. U. (2013), The challenges of ethnonationalism for the Nigerian State, "Journal of African Studies and Development", Vol. 5, No. 3.

Ujumadu V., Agbo D., Herdsmen: 'Buhari's silence dangerous, "Vanguard", https://www.vanguardngr.com/2021/02/herdsmen-buharis-silence-dangerous/ (16.02.2021). 
Ukiwo U. (2008), Horizontal Inequalities and Ethnic Violence: Evidence from Calabar and Warri, Nigeria, in: Horizontal Inequalities and Conflict. Conflict, Inequality and Ethnicity, (ed.) F. Stewart, Palgrave Macmillan, London, https://doi.org/10.1057/9780230582729_9.

VC urges youths not to lose hope, says a better Nigeria will evolve, "Guardian", https://guardian. ng/news/vc-urges-youths-not-to-lose-hope-says-a-better-nigeria-will-evolve/ (21.02. 2020).

Vickers M. (2001), Ethnicity and Sub-Nationalism in Nigeria: Movement for a Mid-West State, WorldView Publishing, Oxford.

Wani A., Suwirta A. (2013), Ethnic Conflict in Nigeria: A Need for True Federalism peaceful and prosperous in Nigeria, "International Journal for Historical Studies", Vol. 5, No. 1.

Welch C. (1995), The Ogoni and Self-Determination: Increasing Violence in Nigeria, "The Journal of Modern African Studies", Vol. 33, No. 4.

Whelan A. (1992), Self-Determination and Decolonisation: Foundations for the Future, "Irish Studies in International Affairs", Vol. 3, No. 4.

\begin{abstract}
Soon after attaining independence on October 1, 1960, the newly created nation-state - Nigeria had to wrestle with post-independent political realities. These combined with the legacies of colonial rule, and the prevalence of ethno-religious politics, led the country into civil war in 1967. Since 1960, Nigeria has experimented with different forms of government and achieved some degree of economic growth but is still plagued by the agitation of self-determination in the form of secessionist campaigns, be it the Biafra or the Oduduwa and Movement for the Emancipation of the Niger Delta (MEND). To place the discussion in perspective, the paper reviews the existing literature on the subject and also discusses Edward Azar's protracted social conflict (PSC) theory as the theoretical base. Upon laying the theoretical foundation, the paper situates and evaluates the agitation for self-determination in Nigeria in the light of PSC. Lastly, the paper concludes that instead of seeking self-determination or territorial disintegration, the polity of Nigeria should historically revert to the practice of congenial and connected regionalism.
\end{abstract}

Keywords: Edward Azar's Protracted Social Conflict Theory, self-determination, communal identity, deprivation of communal needs, governance quality and state

\title{
PRZEWLEKLA TEORIA KONFLIKTU SPOŁECZNEGO I CZYNNIKI SAMOOKREŚLENIA EDWARDA AZARA: PRZYPADEK NIGERII
}

\section{STRESZCZENIE}

Niebawem po tym jak Nigeria uzyskała niepodległość, 1.10 .1960 r., państwo to musiało zmierzyć się z nowymi realiami, potęgowanymi kolonialną przeszłością oraz sporami pomiędzy licznymi mniejszościami religijno-etnicznymi. Efektem była m.in. wojna domowa, która wybuchła w 1967 r. Od samych początków swej państwowości Nigeria eksperymentowała z różnymi formami rządów, którym udało się wprowadzić kraj na tory umiarkowanego rozwoju ekonomicznego. Niestety państwo to wciąż zmaga się z ruchami separatystycznymi nawołującymi do secesji poszczególnych prowincji państwa, np. Biafra, Oduduwa, czy Ruch na rzecz wyzwolenia delty Nigru. Artykuł ten ma na celu m.in. omówienie literatury przedmiotu oraz analizę wspomnianych ruchów separatystycznych ze szczególnym uwzględnieniem ich działal- 
ności agitacyjnej. Podstawę metodologiczną dla autora stanowi teoria przewlekłego konfliktu Edward Azara. Zdaniem autora nigeryjski system polityczny zamiast opierać się na realizacji prawa do samostanowienia poszczególnych grup etnicznych wchodzących w skład Nigerii lub podziałach terytorialnych prowadzących do dezintegracji państwa, powinien powrócić do modelu opartego o regionalizację. Zakłada on autonomię regionów, które współpracując ze sobą w ramach jednego organizmu państwowego potrafiłyby w znacznie efektywniejszy sposób realizować swoje potrzeby, zarówno na poziomie poszczególnych grup etnicznych, jak też i na poziomie jednostki ludzkiej.

Słowa kluczowe: teoria przedłużonego konfliktu społecznego Edwarda Azara, samostanowienie, tożsamość wspólnotowa, pozbawienie potrzeb wspólnotowych, jakość rządzenia i państwo 